\title{
Steroids and terpenoid from Mimosa pudica roots
}

\author{
B. Dinda ${ }^{a *}$. B. Ghosh ${ }^{a}$, S. Arima ${ }^{b}$, N. Sato ${ }^{b}$ and Y. Harigaya ${ }^{b}$ \\ ${ }^{a}$ Department of Chemistry, Tripura University, Suryamaninagar, Agartala-799 130, Tripura. India \\ E-mail : dindabtu@rediffmail.com Fax : 91-0381-2374801 \\ ${ }^{b}$ School of Pharmaceutical Sciences, Kitasato University, Minato-ku, Tokyo-108 8641, Japan
}

Manuscript received 23 February 2006, revised 4 May 2006, accepted 3 July 2006

\begin{abstract}
One new sterolglucoside 1 along with stigmasterol, $\beta$-sitosterol and betulinic acid isolated from the roots of

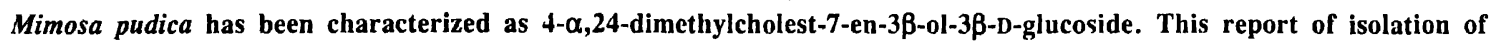
stigmasterol and betulinic acid is for the first time from this plant and $\beta$-sitosterol was reported earlier from its aerial parts.
\end{abstract}

Keywords : Mimosa pudica, Mimosaceae, steroids, terpenoid.

Mimosa pudica L. (Mimosaceae) (local name : Lajak, Lajjabati), a tropical deciduous undershrub of American species $^{1}$ is naturalized in tropical and sub-tropical regions of India. In traditional medicine the decoction of the root is used in gravel and other urinary complaints and in the treatment of piles and fistula ${ }^{2}$. Earlier investigations on the aerial parts of the plant reported the isolation of 4- $O$-(3,5-dihydroxybenzoic acid)- $\beta$-D-glucuronide, D-pinitol, nor-epinephrine, $\beta$-sitosterol, $C$-glycosyl flavones and phenolic ketone ${ }^{3}$. We investigated the roots of this plant for the first time to isolate the active principles present in it and isolated one new sterolglucoside 1 along with known compounds, stigmasterol, $\beta$-sitosterol and betulinic acid.

\section{Results and discussion}

Sterolglucoside 1, amorphous powder, responded the Liebermann Burchard test for steroids. The positive ionFAB-mass spectrum showed a quasi-molecular ion peak at $m / z 599[\mathrm{M}+\mathrm{Na}]^{+}$as well as elemental analysis corresponded to its molecular formula $\mathrm{C}_{35} \mathrm{H}_{60} \mathrm{O}_{6}$. The IR spectrum in $\mathrm{KBr}$ indicated the presence of hydroxyl (3446 $\left.\mathrm{cm}^{-1}\right)$ and trisubstituted olefinic $(1650,824$ and 812 $\mathrm{cm}^{-1}$ ) functions. The $400 \mathrm{MHz}{ }^{1} \mathrm{H}$ NMR spectrum (see Experimental) comprised of a signal for one olefinic proton at $\delta 5.22$ (brd, $\mathrm{H}-7$ ), two methyl singlets at $\delta 0.54$ $\left(\mathrm{H}_{3}-18\right)$ and $0.86\left(\mathrm{H}_{3}-19\right)$, five methyl doublets at $\delta 0.88$ (3H, d, J $\left.6.0 \mathrm{~Hz}, \mathrm{H}_{3}-30\right), 0.78\left(3 \mathrm{H}, \mathrm{d}, J 6.8 \mathrm{~Hz}, \mathrm{H}_{3}-28\right)$, $0.79\left(3 \mathrm{H}, \mathrm{d}, J 6.8 \mathrm{~Hz}, \mathrm{H}_{3}-27\right), 0.86$ (3H. d, J $6.8 \mathrm{~Hz}, \mathrm{H}_{3}$ 26) and $0.95\left(3 \mathrm{H}, \mathrm{d}, J 6.5 \mathrm{~Hz}, \mathrm{H}_{3}-21\right)$, a secondary carbinol methine at $\delta 3.45(1 \mathrm{H}$, ddd, $J 11.5,4.5 .2 .5 \mathrm{~Hz}$, $\mathrm{H}-3)$ and an anomeric sugar proton at $\delta 4.27$ (d, $J 8.0$ $\mathrm{Hz}$ ) suggesting its $4 \alpha$-methyl $\Delta^{7}$-sterolglucoside structure $e^{4,5}$. The upfield $\mathrm{C}-18$ and $\mathrm{C}-19$ methyl protons and C-7 olefinic proton resonances indicated that it was a $\Delta^{7}$ sterol $^{6}$. The chemical shift values of two olefinic carbons in the ${ }^{13} \mathrm{C}$ NMR spectrum (see Experimental) at $\delta 117.82$ (d, C-7) and 140.05 (s, C-8) also corroborated the position of olefinic double bond at C-7. The downfield C-3 and C-5 carbon resonances also supported the alpha $(\alpha)$ configuration of C-4 methyl group ${ }^{7}$. The positive ionFAB-mass spectrum recorded a quasi-molecular ion peak at $m / z 599(\mathrm{M}+\mathrm{Na})^{+}$and significant mass peaks at $\mathrm{m} / \mathrm{z}$ $447\left(\mathrm{M}^{+}\right.$-side chain $\left(\mathrm{C}_{9} \mathrm{H}_{19}\right)$ and $\left.-2 \mathrm{H}\right), 414\left(\mathrm{M}^{+}\right.$-glucosyl $+\mathrm{H}), 398\left(\mathrm{M}^{+}\right.$-glucosyl and $\left.\mathrm{CH}_{3}\right), 396\left(\mathrm{M}^{+}\right.$-glucose $)$, $381\left(\mathrm{M}^{+}-\mathrm{CH}_{3}\right.$ and glucose), $287(\mathrm{M}+\mathrm{H}$-glucosyl and side chain [SC]), 269 (M-SC and glucose), 245 (287$\mathrm{C}_{3} \mathrm{H}_{6}$ [part of ring D]) and $227\left(\mathrm{M}^{+}\right.$-glucose, SC and $\mathrm{C}_{3} \mathrm{H}_{6}$ [part of ring D]) corroborating $4 \alpha, 24$-dimethyl sterol structure with a double bond in the nucleus ${ }^{8}$. The compound on hydrolysis with aqueous-methanolic $\mathrm{HCl}$ gave a free sterol (1a), m.p. $154^{\circ} \mathrm{C}, \mathrm{C}_{29} \mathrm{H}_{50} \mathrm{O}\left(\mathrm{M}^{+} 414\right)$, whose spectral data (see Experimental) were similar to those of 24-methyllophenol ${ }^{5}$. The sterol 1a on acetylation with $\mathrm{Ac}_{2} \mathrm{O}$ and pyridine afforded monoacetate, $\mathbf{1 b}$ $\mathrm{C}_{31} \mathrm{H}_{52} \mathrm{O}_{2}\left(\mathrm{M}^{+} 456\right)$, m.p. $139^{\circ} \mathrm{C}$ (lit. $\left.{ }^{5} 138-139{ }^{\circ} \mathrm{C}\right)$. On the basis of these data, the structure of 1 was deduced as 24-methyllophenol glucoside or $4 \alpha .24$-dimethylcholest-

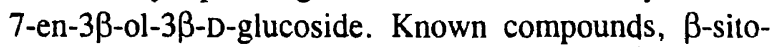
sterol, stigmasterol and betulinic acid were identified by 
comparing their physical and spectral data (see Experimental) with literature values.

Antibacterial screening of the isolated compounds indicated that 24-methyllophenol glucoside was active against Bacillus subtilis $(100 \mu \mathrm{g} / \mathrm{disc})$ and 24-methyllophenol against Pseudomonas aeruginosa (100 $\mu \mathrm{g} / \mathrm{disc})$. The details of screening study of several phytochemicals has been communicated to a biomedical Journal.

\section{Experimental}

The melting points were recorded on a sulphuric acid bath in open capillary tube and are uncorrected. The UV spectra were recorded on a Perkin UV spectrophotometer and IR spectra on a Perkin FTIR spectrophotometer. The ${ }^{1} \mathrm{H}$ and ${ }^{13} \mathrm{C}$ NMR spectra were recorded on a Varian XL 400 spectrometer operating at $400 \mathrm{MHz}$ for ${ }^{1} \mathrm{H}$ and $100 \mathrm{MHz}$ for ${ }^{13} \mathrm{C}$ NMR. EI-MS and FAB-MS were recorded on a JEOL JMS AX 505 HA and a JEOL JMS 700 Mstation spectrometers. For FAB-MS, $m$-NBA, PZG 200 and $\mathrm{NaI}$ were used as matrix and ehloroform-methanol $(1: 1)$ as solvent. Column chromatography (CC) was carried out with silica gel (60-120 mesh, Qualigens, India) and thin layer chromatography (TLC) on silica gel G (Merck, India), respectively.

Plant material : The fresh plant material (roots of $M$. pudica) was collected from the campus area of Tripura University (TU) during October, 2003 and was identified by Dr. B. K. Dutta, Taxonomist, Department of Life Sciences, Tripura University.

Extraction and isolation : Air-dried powdered roots $(2.5 \mathrm{~kg})$ of $M$. pudica was extracted with $\mathrm{MeOH}$ in a percolator. The $\mathrm{MeOH}$ extract was concentrated to a resinous residue $(50 \mathrm{~g})$. The residue was suspended in water (ca. $50 \mathrm{~mL}$ ) and extracted with benzene. chloroform and $n$-butanol, respectively. The benzene fraction on $\mathrm{CC}$ gave a residue of a sterol mixture from benzene-chloroform (9:1) eluate, which on repeated $\mathrm{CC}$ afforded $\beta$-sitosterol (15 mg), $\mathrm{C}_{29} \mathrm{H}_{50} \mathrm{O}$, m.p. $138{ }^{\circ} \mathrm{C}$ and stigmasterol (25 $\mathrm{mg}), \mathrm{C}_{29} \mathrm{H}_{48} \mathrm{O}$, m.p. $170{ }^{\circ} \mathrm{C}$. Both these sterols were identified by comparison of spectral data with literature $e^{4,9}$ as well as direct comparison (m.m.p. and co-TLC) with the authentic samples. The chloroform fraction on $\mathrm{CC}$ afforded stigmasterol $(8 \mathrm{mg})$ from benzene-chloroform ( $7: 3$ ) eluate and betulinic acid $(30 \mathrm{mg}), \mathrm{C}_{30} \mathrm{H}_{48} \mathrm{O}_{3}\left(\mathrm{M}^{+}\right.$ 456), m.p. $316^{\circ} \mathrm{C}$ from chloroform eluate. Betulinic acid was identified by comparison of its spectral $\left({ }^{1} \mathrm{H},{ }^{13} \mathrm{C}\right.$ NMR and EI-MS) data with literature ${ }^{10}$ as well as by direct comparison with an authentic sample. The $n$-butanol fraction on CC afforded betulinic acid $(15 \mathrm{mg})$ from chloroform-methanol $(9: 1)$ eluate and sterolglucoside 1 (120 mg) from ethyl acetate eluate.

Compound 1 : Amorphous powder, m.p. $245{ }^{\circ} \mathrm{C}$ (Found : $\mathrm{C}, 72.76 ; \mathrm{H}, 10.41 . \mathrm{C}_{35} \mathrm{H}_{60} \mathrm{O}_{6}$ requires : $\mathrm{C}$, $72.88: \mathrm{H}, 10.48 \%)$; UV (MeOH) $\lambda_{\max } 248 \mathrm{~nm}(\log \varepsilon$, 3.6); IR (KBr) 3446, 1650, 1523, 1460, 1378, 1060 , $824,812 \mathrm{~cm}^{-1} ;{ }^{1} \mathrm{H}$ NMR (400 $\mathrm{MHz}, \mathrm{CDCl}_{3}-\mathrm{CD}_{3} \mathrm{OD}$, 9 : 1) $\delta 3.45$ (1H, ddd, $J 11.5,4.5$ and $2.5 \mathrm{~Hz}, \mathrm{H}-3)$, $1.76(1 \mathrm{H}, \mathrm{m}, \mathrm{H}-4), 1.40(1 \mathrm{H}, \mathrm{m}, \mathrm{H}-5), 1.82(2 \mathrm{H}, \mathrm{m}$, $\left.\mathrm{H}_{2}-6\right), 5.22$ (1H, brd, J $\left.5.5 \mathrm{~Hz}, \mathrm{H}-7\right), 0.54$ (3H. s, $\mathrm{H}_{3}$ 18), $0.86\left(3 \mathrm{H}, \mathrm{s}, \mathrm{H}_{3}-19\right), 0.95$ (3H, d, J $6.5 \mathrm{~Hz}, \mathrm{H}_{3}-21$ ), $0.86\left(3 \mathrm{H}, \mathrm{d}, J 6.8 \mathrm{~Hz}, \mathrm{H}_{3}-26\right), 0.79(3 \mathrm{H}, \mathrm{d}, J 6.8 \mathrm{~Hz}$, $\left.\mathrm{H}_{3}-27\right), 0.78\left(3 \mathrm{H}, \mathrm{d}, J 6.8 \mathrm{~Hz}, \mathrm{H}_{3}-28\right), 0.88(3 \mathrm{H}, \mathrm{d}, J$ $\left.6.0 \mathrm{~Hz}, \mathrm{H}_{3}-30\right), 4.27\left(1 \mathrm{H}, \mathrm{d}, J 8.0 \mathrm{~Hz}, \mathrm{H}-1^{\prime}\right), 3.12(1 \mathrm{H}$, dd, $J 9.0$ and $\left.8.0 \mathrm{~Hz}, \mathrm{H}-2^{\prime}\right), 3.29(1 \mathrm{H}, \mathrm{dd}, J 9.0$ and 9.0 Hz. H-3'), $3.27\left(1 \mathrm{H}\right.$, dd, J 9.0 and $\left.8.0 \mathrm{~Hz}, \mathrm{H}-4^{\prime}\right), 3.15$ (1H, ddd, $J$ 9.0, 4.5 and $\left.2.5 \mathrm{~Hz}, \mathrm{H}-5^{\prime}\right), 3.62(1 \mathrm{H}$, dd, $J$ 12.5 and $\left.4.5 \mathrm{~Hz}, \mathrm{H}_{\mathrm{a}}-6^{\prime}\right), 3.71(1 \mathrm{H}$, dd, $J 12.5$ and 2.5 $\left.\mathrm{Hz}, \mathrm{H}_{\mathrm{b}}-6^{\prime}\right) ;{ }^{13} \mathrm{C}$ NMR (100 MHz, $\left.\mathrm{CDCl}_{3}-\mathrm{CD}_{3} \mathrm{OD}, 9: 1\right)$ $\delta 36.78$ (t, C-1), 31.61 (t, C-2), 78.88 (d, C-3), 40.23 (d, C-4), 51.01 (d, C-5), 29.42 (t, C-6 ), 117.82 (d, C-7), 140.05 (s, C-8), 49.93 (d, C-9), 36.44 (s, C-10), 20.78 (t, C-11), 39.50 (t, C-12), 42.05 (s, C-13), 55.70 (d, C14), 25.11 (t, C-15), 27.95 (t, C-16), 56.49 (d, C-17), 11.86 (q, C-18), 15.01 (q, C-19), 35.87 (d, C-20), 18.97 (q, C-21), 33.67 (t, C-22), 29.99 (t, C-23), 38.58 (d, C24), 32.14 (d, C-25), 20.86 (q, C-26), 18.35 (q, C-27), 15.01 (q, C-28), 15.07 (q, C-30), 100.84 (d, C-1'), 73.30 (d, C-2'), 76.19 (d, C-3'), 69.95 (d, C-4') 75.53 (d, C$5^{\prime}$ ), 61.59 ( t, C-6'); HR-FAB-MS m/z 599.4278 (rel. int. $100 \%$ ). Calcd. for $\mathrm{C}_{35} \mathrm{H}_{60} \mathrm{O}_{6}$. Na 599.4288; positive ionLR-FAB-MS $\mathrm{m} / \mathrm{z}$ (rel. int. \%) $599(\mathrm{M}+\mathrm{Na}, 5), 447$ (6), 414 (10), 398 (58), 396 (48), 381 (11), 287 (11), 269 (7), 245 (21), 227 (11), 127 (31), 71 (49), 57 (85), 43(100).

Acid hydrolysis of compound 1 : A solution of compound $1(30 \mathrm{mg})$ in aqueous methanolic $1 \mathrm{M} \mathrm{HCl}(10$ $\mathrm{mL}$ ) was refluxed for $2 \mathrm{~h}$ and monitored by TLC. The TLC of the reaction mixture showed disappearance of 1 . The reaction mixture was evaporated on boiling water bath to remove methanol, diluted with water and extracted with chloroform. The chloroform extract was washed with water, concentrated and subjected to $\mathrm{CC}$ to get aglycone, 24-methyllophenol 1a (12 mg), m.p. $154^{\circ} \mathrm{C}$. The aqueous layer left after chloroform extraction of the concentrated reaction mixture was neutralized with $\mathrm{Ag}_{2} \mathrm{CO}_{3}$, filtered and the filtrate was concentrated. The concentrated solution on TLC and optical rotation study (+ve rotation) showed the presence of D-glucose $\left(R_{\mathrm{f}} 0.48, n\right.$ butanol-pyridine- $\mathrm{H}_{2} \mathrm{O}, 6: 4: 3$ ). 
Compound 1a : Colourless, crystals, m.p. $154^{\circ} \mathrm{C}$ : IR (KBr) 3616. 1652. 1523, 1461, 1048, 824, $813 \mathrm{~cm}^{-1} ;{ }^{1} \mathrm{H}$ NMR (400 MHz. $\left.\mathrm{CDCl}_{3}\right) \delta 3.52(1 \mathrm{H}, \mathrm{H}-3), 5.20(1 \mathrm{H}$, brd, H-7), 0.54 (3H, s, H $\left.\mathrm{H}_{3}-18\right), 0.85\left(3 \mathrm{H}, \mathrm{s}, \mathrm{H}_{3}-19\right)$, $0.94\left(3 \mathrm{H}, \mathrm{d}, J 6.5 \mathrm{~Hz}, \mathrm{H}_{3}-21\right), 0.86(3 \mathrm{H}, \mathrm{d}, J 6.8 \mathrm{~Hz}$, $\left.\mathrm{H}_{3}-26\right), 0.80$ (3H, d, J $\left.6.8 \mathrm{~Hz}, \mathrm{H}_{3}-27\right), 0.78(3 \mathrm{H}, \mathrm{d}, J$ $\left.6.8 \mathrm{~Hz}, \mathrm{H}_{3}-28\right), 0.85\left(3 \mathrm{H}, \mathrm{d}, J 6.0 \mathrm{~Hz}, \mathrm{H}_{3}-30\right) ;{ }^{13} \mathrm{C}$ NMR (100 MHz, CDCl $) \delta 37.00$ (t, C-1), 28.33 (t, C2), 77.82 (d, C-3), 38.20 (d, C-4), 50.13 (d, C-5), 27.95 (t, C-6), 117.22 (d, C-7), 139.40 (s, C-8), 50.15 (d, C9), 36.50 (s, C-10), 21.18 (t, C-11), 39.51 (t, C-12), 42.21 (s, C-13), 54.39 (d, C-14), 23.06 (t, C-15), 28.18 (t,.C-16), 56.11 (d, C-17), 11.97 (q, C-18), 14.10 (q, C19), 36.14 (d, C-20), 18.77 (q, C-21), 35.67 (t, C-22), 24.29 (t, C-23), 39.07 (d, C-24), 29.12 (d, C-25), 21.02 (q, C-26), 18.97 (q, C-27), 15.36 (q, C-28), 15.43 (q, C30); EI-MS m/z (rel. int.) $414\left(\mathrm{M}^{+}, 40\right), 399$ (M-Me, 42). $396\left(\mathrm{M}-\mathrm{H}_{2} \mathrm{O}, 22\right), 381\left(\mathrm{M}-\mathrm{H}_{2} \mathrm{O}\right.$ and $\left.\mathrm{Me}, 25\right), 287$ (28), 269 (14), 245 (21), 227 (35), 127 (63), 71 (73), 57 (100), 43 (87).

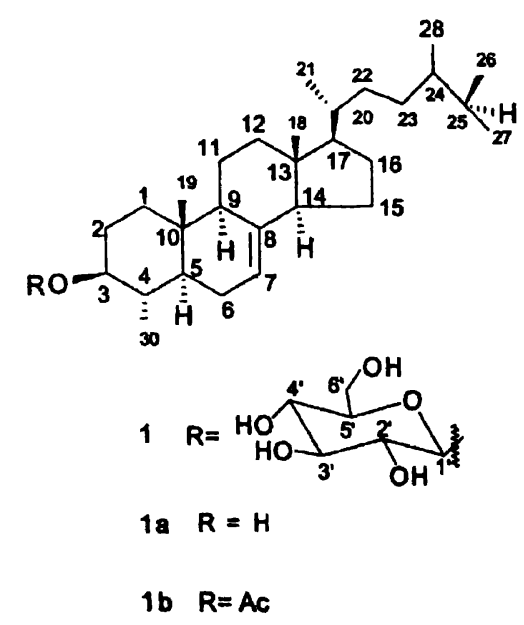

Acetylation of compound 1a : Compound 1a (6 mg) was acetylated with $\mathrm{Ac}_{2} \mathrm{O}(1 \mathrm{~mL})$ and pyridine (4 drops) at room temperature for $24 \mathrm{~h}$. The acetylated mixture on usual work-up followed by column purification afforded monoacetate $\mathbf{1 b}$ in colourless crystals $(2 \mathrm{mg})$, m.p. 139 ${ }^{\circ} \mathrm{C} . \mathrm{C}_{31} \mathrm{H}_{52} \mathrm{O}_{2}\left(\mathrm{M}^{+} 456\right)$; IR (KBr) 1735, 1260 (OAc), $830,815 \mathrm{~cm}^{-1}\left(>\mathrm{C}=\mathrm{CH}^{-}\right)$.

\section{Acknowledgement}

This research work was supported by a fund (G-12/ 2001) from the Department of Science and Technology, Govt. of India, New Delhi. The authors are thankful to Chemistry Department, Gauhati University for IR spectra and CDRI, Lucknow for micro analysis.

\section{References}

1. D. B. Deb, "The Flora of Tripura State". Vol. 1, Today \& Tomorrow's Printers and Publishers, New Delhi, 1981, p. 133.

2. R. N. Chopra, S. L. Nayar and I. C. Chopra, "Glossary of Indian Medicinal Plants". Publications \& Information Directorate, CSIR, New Delhi, 1992, p. 167; A. Husain, O. P. Virmani, S. P. Popli, L. N. Misra, M. M. Gupta, G. N. Srivastava, Z. Abraham and A. K. Singh, "Dictionary of Indian Medicinal Plants". CIMAP, Lucknow, 1992, p. 302.

3. B. Josewin, M. Ramachandrapai and M. S. Suseelan. Indian J. Chem., Sect. B, 1999, 38, 251 and other references cited therein; A.Lobstein, B. Weniger. B. H. Um, M. Steinmetz, L. Declercq and R. Anton, Biochem. System. Ecology, 2002, $30,375$.

4. I. Rubinstein, L. J. Goad, A. D. H. Clague and L. J. Mulheirn, Phytochemistry, 1976, 15, 195.

5. T. Itoh, T. Ishii, T. Tamura and T. Matsumoto, Phytochemistry, 1978, 17, 971 .

6. N. S. Bhacca and D. H. Williams, "Applications of NMR Spectroscopy in Organic Chemistry", Holden-Day, San-Francisco, 1964.

7. T. Akihisa, ${ }^{13}$ CNMR Spectral Identification of Sterols in "Analysis of Sterols and Other Biologically Significant Steroids", eds. W. David Nes and E. J. Parish, Academic Press, London, 1989, p. 251.

8. S. G. Wyllie and C. Djerassi, J. Org. Chem., 1968, 33, 305.

9. H. L. Holland, P. R. P. Diakow and G. J. Taylor, Can. J. Chem., 1978, 56, 3121.

10. S. Siddiqui, F. Hafeez, S. Begum and B. S. Siddiqui, $J$. Nat. Prod., 1988, 51, 229; B. Dinda, A. K. Hajra, S. K. Das, G. Chel, R. Chakraborty and B. C. Ranu, Indian J. Chem., Sect. B, 1995, 34, 624. 